Article

\title{
(Re)forming the Inside/Outside: On Place as a Governable Domain through Sports-Based Interventions
}

\author{
David Ekholm * and Magnus Dahlstedt \\ Department of Culture and Society, Linköping University, 60174 Norrköping, Sweden; E-Mails: david.ekholm@liu.se (D.E.), \\ magnus.dahlstedt@liu.se (M.D.) \\ * Corresponding author
}

Submitted: 4 December 2019 | Accepted: 25 February 2020 | Published: 17 August 2020

\begin{abstract}
This article draws attention to two sports-based interventions carried out as part of the Midnight Football initiative and the places where they are conducted in two suburban areas in Sweden. Rather than approaching geographic place as simply a background and a context for sport-based interventions, we put place in the spotlight, scrutinising the very formation of place and its productive role in governing social policy. In line with a Foucauldian approach, and based on interviews and ethnographic fieldwork, the aim of the article is to explore how the specific localities where interventions take place are formed as governable domains. The analysis shows how place is constituted in association with sport sites, local youth outreach and recruiting coaches. These places are made distinct from the rest of the surrounding cities via material and symbolic borders, directing the movement of people within the urban geography. These differentiations underpin attributions of the areas in terms of otherness and exclusion from the rest of society, localising a variety of problematisations to the demarcated areas. Furthermore, the places are demarcated as being filled with danger, intertwined with narratives challenging such a discourse. In conclusion, the findings enable us not only to scrutinise how specific meanings are attributed to place and how place is formed, but also to explore the performative and governable potential of place.
\end{abstract}

\section{Keywords}

football; geography; governmentality; place making; social exclusion; youth

\section{Issue}

This article is part of the issue "Sport for Development: Opening Transdisciplinary and Intersectoral Perspectives" edited by Pascal Delheye (Ghent University, Belgium), Kirsten Verkooijen (Wageningen University \& Research, The Netherlands), Dan Parnell (University of Liverpool, UK), John Hayton (Northumbria University, UK) and Reinhard Haudenhuyse (Vrije Universiteit Brussel, Belgium).

(C) 2020 by the authors; licensee Cogitatio (Lisbon, Portugal). This article is licensed under a Creative Commons Attribution 4.0 International License (CC BY).

\section{Introduction}

In recent years, the suburban landscape in Sweden, as in many other Western welfare states (Dikec, 2017), has undergone significant transformations regarding an increase in segregation and exclusion (Franzén, Hertting, \& Thörn, 2016). Here, the significance of place, as a container for problems and interventions, has been prominent in contemporary policy discourse (Sernhede, Thörn, \& Thörn, 2016). In this context, sports-based interventions have been suggested as a means of social change, targeting in particular the youth of the urban peripheries (e.g., Parker, Morgan, Farooq, Moreland, \& Pitchford, 2019). Since sports-based interventions are becoming more widespread and integrated as forms of governing social policy (e.g., Collins \& Haudenhuyse, 2015), our point of departure is that such interventions can be analysed as sites of governing social problems, individuals and populations (e.g., Ekholm, 2018; Kelly, 2013).

Even though places are a recurrent theme in studies on sports-based interventions, there seems to be little or no scrutiny in research of the formation of place as such. We argue that understanding the productive role and performativity of place is pivotal for assessing gov- 
erning interventions as part of contemporary social policy. Place is more than the location of problems and interventions; it is a force of policy in its own right. Rather than approaching the places and areas of the urban periphery simply as a background and context for sportbased interventions, we position these in the spotlight of investigation, interrogating the very discursive formation (cf. Foucault, 1972) of place in terms of domains of governing (cf. Rose, 1999).

In this interrogation, we specifically direct our attention to two sports-based interventions, carried out as part of the Midnight Football initiative, in the urban periphery of Sweden-more specifically, in West City (and the suburban area Västerort) and East City (and the suburban area Österort), two neighbouring cities and municipalities of similar sizes (with populations between 100,000 and 200,000 people). The aim of this article is to explore how the specific suburban areas where the interventions take place are formed in discourse as governable domains and how the particular rationalities are interrelated to broader social policy discourse.

Midnight Football is a nationwide sports-based intervention, designed by a national corporate social responsibility foundation, and implemented in collaboration with local agencies and associations. The activities take place in an urban geography characterised by socioeconomic disadvantages, in collaboration with Suburbia FC in West City and Sumeria FC in East City. Both Västerort, in West City, and Österort, in East City, are recognised as prioritised areas in local social and municipal policy and have been identified as particular targets for interventions. Participants, managers and coaches tend to come from the specific residential areas where the activities take place. The interventions are performed by local sports associations, one at each site, providing resources in the form of local managers and coaches. Municipal agencies are partners, providing support and collaboration to varying degrees. In West City, the municipality provides minor association grants, while in East City, the municipality provides significant funding through an assignment agreement (Ekholm, 2019). Moreover, the interventions are supported by sponsors and charitable community actors (Ekholm \& Dahlstedt, 2018). The sport activities - five-a-side indoor football on Saturday evenings at 20:00-target young people aged 12-25 (Ekholm \& Dahlstedt, 2019). The overall ambition is to use football to promote social inclusion, prevent crime and facilitate employability. However, the interventions do not have any clear programme theory (cf. Coalter, 2012), making these objectives difficult to achieve and evaluate. Still, the activities have a general arrangement and routine (the coaches divide the young people into teams, the first team to score wins, the winning team remains on the pitch, and subsequent teams come onto the pitch in turn), as well as an implicit understanding of socio-pedagogical elements of the learning and social relations provided through Midnight Football guiding the arrangement of activities (Ekholm \& Dahlstedt,
2019). Similar activities are carried out by the foundation through a variety of cross-sector collaborations in up to 20 Swedish municipalities.

\section{Research Context}

In recent decades, economic inequalities have been increasing in Sweden, creating geographic divisions in the urban landscape, with growing patterns of social vulnerability and exclusion. Here, the concentration of subsidised public housing in urban outskirts in conjunction with socioeconomic divisions (shaped by ethno-cultural segregation) have laid the foundation for advanced spatial segregation (Franzén et al., 2016) - referred to in public debate as "areas of exclusion" (Sernhede et al., 2016). This context of segregation is not unique to Sweden. Rather, such patterns can be recognised in most developed societies (Dikec, 2017).

A range of studies on the sociology of sport have paid attention to the geographical locations where sportsbased interventions take place. Here, urban peripheries have been seen as sites needing interventions for social change, targeting certain populations, not least those referred to as "at-risk youth" (e.g., Hartmann, 2016). However, there is a tendency in existing literature to take the conditions of exclusion and segregation in the urban geography as a given context and framework for the sports-based interventions examined. Such literature situates examinations to "social housing" areas (e.g., Collins \& Haudenhuyse, 2015) and "deprived areas" (e.g., Coalter, Allison, \& Taylor, 2000), or specifically to "inner-city" areas in the US (e.g., Bustad \& Andrews, 2017), "estates" in the UK (e.g., Morgan, 2018), "disadvantaged communities" in Australia (e.g., Skinner, Zakus, \& Cowell, 2008) and "areas of exclusion" in Scandinavia (Ekholm \& Dahlstedt, 2017). Such terms for places are euphemisms for deprived and distressed residential areas located in the urban periphery. In the existing literature, there has been a repeated focus on the forces and consequences of neoliberalism, in terms of segregation and deprivation in the neighbourhoods of the poor and the excluded (e.g., Collins \& Haudenhuyse, 2015). Importantly, this literature provides clear critical reflections on how inequalities and processes of exclusion play out and on the conceptual foundation of the promotion of sport as a response to such processes (e.g., Hartmann, 2016). However, in line with a predominant conception of place, less effort is made to explore, in greater detail, the various meanings and symbolic forces producing the places themselves.

Turning to literature on critical urban geography, considerable attention has been paid to the meanings of place as something more than just a physical territory, a landscape where various problems and interventions are located. Here, the analytical focus is directed on the very production of space, illustrating how social processes in space, together with representations of space, help to produce places in specific ways (Lefebvre, 1991). In this 
respect, the constructed meanings of place have productive effects in terms of conditioning how processes of both inclusion and exclusion are formed (Zukin, 1995). Thus, in order to further investigate places and their productive effects, "it is necessary to examine the assumptions about inclusion and exclusion which are implicit in the design of spaces and places" (Sibley, 1995, p. x). Based on this assertion, we make no claim to provide a full examination of the role of place in relation to sportsbased interventions. However, in this article, we make the case that there is a point to be made about seeing the formation of place as integral to the forms of governing promoted. Moreover, we provide the contours of a framework for such an examination, beyond showcasing how such an empirical examination can be conveyed and what it may discern.

\section{Theoretical and Methodological Framework}

In line with a Foucauldian approach, discourse refers to different ways of talking about and understanding certain things and objects (Foucault, 1980, 1982). Foucault (1972) stresses that concepts are formed in relation to other concepts, by association and differentiation. He uses the term discursive formation to describe how objects (such as places) are formed. Two particularly important points about discursive formations can be made, pinpointing how the world, concepts and the ways in which objects are formed could be different and have been produced through struggles and power relations, and how discourse and statements constitute a productive and performative force, producing objects in ways that enable them to be acted upon (Foucault, 1980, 1982). Following such an understanding, the conceptual understanding of places can be approached as discursive formations (cf. Foucault, 1972), with a focus on how they are constructed by certain problematisations and technologies of governing (Rose, 1999). The term problematisation can be described as the discursive formation of a problem. What are perceived as problems become problems in relation to how solutions or technologies of governing are prescribed and talked about. Problematisations are, so to speak, explicitly or implicitly embedded in interventions, solutions and technologies of various kinds and how these are talked about. Thus, problems and solutions are not seen as opposites, but rather as being embedded in the same discourse (Bacchi, 2009). In this respect, the term governing means the actions and interventions promoted to guide the actions and behaviours - or the conduct-of individuals and populations (Foucault, 1982). Accordingly, problematisations and technologies of governing intersect at certain domains. In this article, we use the term domain to describe the discursive formations where the problematisations and technologies of governing are located. Accordingly, such domains can be referred to, for instance, as places, localities, areas, territories or residential areas, meaning the geographical sites of prob- lematisation and governing. Domains are the "abstract spaces" (Rose, 1999, p. 31) and discursive formations where statements about problematisations and technologies of governing are hosted. Thus, domains may be understood as containers of problems and solutions (Rose, 1999). In this sense, domains cannot pre-exist the articulated problematisations and technologies of governing, but are produced through such discourse (Rose, 1999). Forming these domains is an act of animation (cf. Foucault, 1980; Rose, 1999). Animation refers to how the articulation of discourse produces-or animates-a conceptual understanding of the world and its objects (i.e., place) that can be acted upon (Foucault, 1980). The production of domains, in this sense, has been likened to the efforts of a cartographer, animating spaces and objects as visible and controllable demarcations of reality (Rose, 1999).

The empirical material analysed in this article comprises of observations of sports activities carried out at the two sites investigated as well as interviews with managers, coaches, participants, partnering agencies and a variety of representatives from community agencies and authorities. The empirical material presented and investigated in this article was gathered as part of a wider research project, examining both the organisational dimensions of the interventions (Ekholm \& Holmlid, 2020) and the socio-pedagogical outline of social work promoted (Ekholm \& Dahlstedt, 2019). Observations were conducted on five occasions at each site, and field notes were taken and transcribed. In this article, field notes provide a context for the interpretations and analysis made (cf. McSweeney \& van Luijk, 2019), not least with respect to the familiarity of the suburban geography and the meaning attributed to it, as scrutinised in this article. 60 semi-structured interviews were undertaken, focusing on the role of sport in combating social problems. Three intervention managers, male, aged $25-40$ years old, were interviewed (one in West City and two in East City) alongside nine male coaches, aged 18-30 (all in East City). Further, interviews were conducted with 21 participants aged 15-21, 19 male (seven in West City; twelve in East City) and two female (both in West City). Alongside this, 27 interviews were conducted with sponsors, charitable contributors, municipal partners, community agencies and authorities such as representatives from local schools, social services and the police (nine respondents were involved in both cities, ten in West City and eight in East City). Even though not all these interviews are featured in the presentation of the analysis, all the interviews were analysed and constitute the empirical material explored.

Interviews and observations were conducted by the authors of the article and two research assistants; a few additional interviews were conducted by a team of undergraduates. Both the authors and the assistants are familiar with the areas (and similar areas) where the research was conducted. The authors have a native Swedish background, while the assistants are from mi- 
grant backgrounds. The composition and previous experiences of the research team have provided access to the field as well as a basis for reflexive approaches to the explorations made.

Guided by the conceptual framework outlined, this empirical material is examined with a focus on how sport is articulated as a response to a variety of social problems. More specifically, we examine how place emerges as a domain in relation to such articulations, as a container for problematisations and technologies of governing. We examine how places are described, how specific meanings are ascribed to places and how certain places are demarcated from other places. In this process of exploration, four themes have been identified, concerning how place is formed around the practices of sport, how places are demarcated from the city and society, how the problems responded to are discursively located in the particular places of intervention, and how danger is ascribed to and reflected upon in relation to the place demarcated. Altogether, the analysis displays the discursive formations and interrelations between how problems and responding interventions are articulated, and how places emerge and are constituted by such discourse.

\section{Results and Analysis}

This analysis is divided into four subsections. First, the analysis shows how place is constituted in association with sport. Second, the localities are discursively made distinct from the rest of the cities by means of material and symbolic borders. Third, these differentiations underpin a discourse and attributions of the locality in terms of otherness and exclusion from the rest of society. Fourth, the localities are demarcated by being animated as full of danger, while narratives challenge this discourse. In this sense, the places are formed as domains integrated within the promoted forms of governing. Notably, these discourses of differentiation and the demarcation of the places are articulated in similar ways via the different positions from which they are examined.

\subsection{Centring the Suburb around the Practices of Sport}

Through a variety of articulations, place is associated with sport practices and the notion of sport as a means of intervention and social change. Three main interconnected facets of the suburban locality centring around sport can be discerned, emphasising how sport practices are conveyed at central locations in the studied areas, how these practices reach out to the local youth in particular, and how coaches are recruited and granted their position on the basis of their local connection.

First, the importance of the sports-based practices conducted at central places in the demarcated suburbs is repeatedly stressed in the discourse. In Västerort, there are two sports centres and football grounds. One is just outside the suburban area, or beyond the road demarcating the boundaries of the residential area and was tra- ditionally used by local football clubs. The other sports field and complex, including the upper secondary school and the main school building, is located in the park at the centre of the surrounding area. When asked in an interview if it would be possible to conduct the activities at the sports ground beyond the road, Martin, the West City Midnight Football manager, responds, "never," furthermore explaining that "the important thing is that it is so local...that it is close," suggesting that "the kids should just get their bags and run out from school and be on the sports ground in two minutes." In this way, he animates a domain where access to sport grounds is constitutive of the place and the movements enabled.

Localising sport activities in general, and the Midnight Football activities in particular, to the central park in Västerort also has a certain importance for the young people in terms of how they move within the area. When sixteen-year-old participant Boban describes how he spends time with his friends, he emphasises that they meet up "around the park...and play football and so on." The park is located near the football field and the upper secondary school. It is also there that young people meet up to attend the Midnight Football activities and hang around during the Midnight Football activities when they are not playing.

The sports complex is also part of the local school in Österort, located centrally within the area. Abraham, one of the managers for East City's Midnight Football activities, says: "Now, the sports centre happens to be where it is....If we want to carry out indoor activities...well, then we need a sports centre." He explains that the location of the venue is not intended to be part of the design of the intervention. Still, the location at the centre of the area gives young people from the area easy access to the activities. Here, the important thing is how the location is part of a general discourse of the place, and how the particular domain is animated around the sports centre even though the infrastructure just "happens" to be located at a particular place.

Second, respondents repeatedly describe how participants are reached out to in relation to where they live within the demarcated suburban areas. The young people's movements revolve around the sports centres in these areas. Almost all the young participants come from Västerort. There are some exceptions, for example young people who live in other socioeconomically disadvantaged areas of West City. This is reaffirmed by seventeen-year-old participant Ali, who states that-and animates how-the young participants are "mainly from [Västerort]," adding that "some might come from other parts," mentioning other areas of socioeconomic deprivation.

Here, it is important to note the primarily local reach of young people when they move around. When exceptions do occur, they move from similar areas to the location of the activities. Looking at East City, Sulejman, East City's other manager, reflects on how young people from Österort are agile in their movement, articulat- 
ing how borders and movements are constructed from different positions. Accordingly, the local young people sometimes attend recreation centres and activities in other parts of the city. However, young people from more affluent residential areas rarely come to Österort and the Midnight Football activities held there:

You can tell by the kids...something I have noticed....Kids from [Österort]...go to the recreation centres in [two other areas]. There is a lot of movement nowadays. It's incredible. They move...they are everywhere.

Interviewer: Do kids from other areas come to [Österort]?

No, I don't think so. Not into these areas. It's usually the kids who live here.

According to this description, recreation centres and sports activities in the area, such as Midnight Football, are more or less exclusively attended by local young people. Local youngsters may move around the city, but young people from other areas do not come to the area. The perceived borders limit movements into the area (of exclusion), and in that sense reinforce the demarcations. The area of exclusion, discursively located in the periphery-the outside-of the city, forms its own logic of exclusion and inclusion. In this sense, it is the young people from areas and localities beyond the area of exclusion that do not enter it, reconfiguring the notions of inside and outside borders and demarcations. Accordingly, young people from outside the (perceived) outside do not enter. Thus, the locality, reach and movement of young people constitute a contrasting discourse of inclusion, re-forming the notions of inside and outside; the area of exclusion (outside) is demarcated from the rest of the city, forming its own 'inside' through the movement of young people.

Third, interrelated to the local movements of participating young people, the discourse formative of the interventions pinpoints how local leaders are a cornerstone of the interventions. Almost all leaders have their backgrounds in these areas and still live there. According to Niklas, who works for the foundation, there is a need for "locally rooted leaders, who know the young people and their movements and who have good connections," in order to reach out to young people. This argument and discourse is generally put forward by managers and coaches (Ekholm \& Dahlstedt, 2019), but also by Harald, a police officer in West City. Harald explains how "[Västerort] is kind of....they don't accept anyone..., but in an area of exclusion, it is essential for leaders to know the locality, principally, to be accepted." The same discourse is repeated in East City. Here, Hans, who represents the elite sport club involved in supporting Midnight Football, pinpoints the importance of a "connection to the area....It's not a game going out there on a Saturday night, I can tell you," emphasising that Saturday nights in the area are dangerous and that this is not a time or a place for recreation.

\subsection{Separating the Suburb from the City and Society}

In order to make the domain distinct, the place needs to be formed and animated as something else, compared to the rest of the cities and society at large. Accordingly, people from other areas do not enter the sites of intervention. Rather, they move within the localities, centring their movements around the sport sites. This discourse can be grasped in two synchronic dimensions, pinpointing how material and symbolic dimensions of separation are articulated and intertwined, reinforcing each other.

First, a range of material dimensions of separation are articulated. In West City, physical borders are clearly marked in the territory. The residential area where Midnight Football takes place, centred around the park, school and sports centre, is clearly demarcated on three sides, bordering the rest of the city: on one side by the main railway tracks, on another side by large industrial sites, and on a third side by a busy motorway. These physical barriers, in turn, are surrounded by large bushes and fields. Demarcated in these directions, the apartment blocks that make up the area are surrounded by a circular road, encapsulating the area from the outside. Martin (Suburbia FC) describes this:

[Västerort] has a geographical barrier in the form of a road that goes around the whole area. So, [Västerort] is geographically encapsulated, with only a few crossing points...difficult bus connections...and if you don't have a driving licence then it's not natural to get out. It's not a prison, definitely not. But there is a very clear mental barrier.

Accordingly, the area is clearly demarcated in the urban geography, with recognised passages directing the movement that is possible (without a car). Importantly, this way of perceiving and reiterating the cartography of the suburban geography is an act of animation, enforcing the contours of the domain in relation to the perceived barriers. Apartment blocks face the inside of the area where the park, school, sports centre and football fields are located. Demarcations to the outside allow for open spaces in the park and suburban centre-as commented on by Klas, the owner of an industrial factory that sponsors Midnight Football. Referring in particular to the circular road, he says that "this ring isn't very fortunate, but the inside provides...a community space, and that's a real opportunity."

In Österort, the borders are more invisible to the uninitiated visitor, although they are clear to residents. Neighbouring residential areas blend into each other. Despite being demarcated by large motorways in two directions, there are generally more passages compared to Västerort. When asked about the border towards 
the neighbouring residential area of Österort, manager Abraham (Sumeria FC) says that the border "is not there, it's not physically there." He then explains which apartment blocks and buildings belong to which residential area, thereby introducing and animating the symbolic borders in the landscape. He emphasises that people who move between the areas recognise the boundaries, in terms of both material and symbolic dimensions, and says that there is a general notion that "you shouldn't be on the other side," in that sense describing the normative significance of symbolic borders restricting the movement of young people.

Second, as noted above, the material dimensions of separation become meaningful and able to be acted upon in their symbolic dimensions. The material borders are highly visible in West City but are primarily described in terms of their symbolic manifestation in East City. In the following, Abraham expounds on the borders separating Österort from nearby localities:

You can compare [Söderort] to [Österort]. They are really close. There is a damn invisible border in between. It has been there ever since I was a kid. If you live in [Söderort], you go to [Söderort school], you are a [Söderort] guy, then you don't hang out in [Österort]....We have thought about sharing weeks...one week [Österort], the other week [Söderort]....Damn, this is great fun. Yes, excellent. Then you cross the border next week if you want to join.

The borders are traditional; they are "invisible," but are still powerful in terms of steering the movement of young people, limiting the extent to which Midnight Football participants cross into other areas. Moreover, borders are continuously mobilised, for instance by administrative divisions into school areas, creating symbolic demarcations that help to shape a sense of residential belonging.

Notwithstanding the degree to which borders are physical, they become symbolic barriers in discourse on how areas are demarcated. Even when they are not as clearly visible in the territory, the symbolic boundaries are clearly noticed by residents. Confirming the symbolic observance of borders expressed by Abraham, Eva-a civil servant with the East City municipal culture and leisure administration-speaks about the municipality's general interest in supporting the intervention. She says it is important to "have a connection... like integration between areas, where...there is like a wall [and] sharp delineation," limiting the opportunities for young people from outside Österort to "get to the sports centre" and participate in Midnight Football. Accordingly, the policy objectives guiding the municipal administration's interest in reaching out to young people via sport have to challenge the symbolic forces of barriers in the suburban geography.

\subsection{Problematising the Place}

When separated from the rest of its city, each locality has its own internal characterisations. In the discourse, the local residents are described in various ways as being excluded and as other, and in particular as being vulnerable. These problematisations concern how vulnerability and exclusion create specific challenges located to and contained within the areas, suggesting that certain conditions need to be taken into account for those who operate there.

First, socioeconomic vulnerability is associated in a variety of ways with the areas where the Midnight Football interventions take place. This vulnerability creates difficult conditions and specific challenges for organising sports practices within traditional associations, including due to difficulties in terms of paying membership fees and parental involvement. Habwir, a participant in West City Midnight Football in his early twenties, describes how Midnight Football "provides an opportunity to practise football for free" for young people who cannot afford to join teams. Marika, the chair of the municipal board for leisure and culture in West City, explains how the vulnerability in Västerort result in a certain sense of despair among young people who live there. According to Marika, "a lot of people are unemployed and have nothing to do during the day." They "live on social benefits and many of the kids have never seen their parents go to work," so the kids "have no hope of ever getting a job themselves" and "they lose hope." Through discourse and animation, the domain is formed as a site for challenges and needs as well as governing measures, which are specifically located to the area and not to other parts of the city.

Marika acknowledges how the residents' socioeconomic vulnerability also creates challenges for sport associations, recalling that "there were so many failures [and] difficulties in forming lasting associations." Along these lines, Azad, who works as an integration coordinator with the district sports federation, describes how "associations out in these areas face severe difficulties...and they are weak in terms of resources." Specifically, he mentions an association previously active in Västerort, saying "they were an association with many teams...but teams just disappear." It is on this basis that Bernt, secretary of the charitable gentlemen's club, justified the club's support for Midnight Football: "We could have given money to some team in [an affluent area], but they are too privileged." There, "they have money, coaches, adults around who can provide support," but "that's not the case in [Västerort]." All of these challenges are mirrored in East City and Österort, with the exception that Sumeria FC functions well as a sports club, with a long tradition of providing sport activities. Still, Sulejman from Sumeria FC believes that the activities of Midnight Football can be seen as a form of social work, responding to challenges of deprivation and exclusion. Accordingly, many young people "were excluded because they could 
not afford...membership fees." But the open forms of Midnight Football "mean a form of integration," which, for Sulejman, "is, in a sense, social work."

Second, the current patterns of segregation in each city, and the socioeconomic deprivation in Västerort and Österort, are also recognised in local policy and municipal administration (Ekholm, 2019). Both Västerort and Österort are repeatedly talked about, and thus animated, as places in need of support and governing interventions. Therefore, Midnight Football has appeared on the local political agenda. Sulejman reflects on the terms under which Österort is targeted by the benign forms of governing in the municipal administration:

We were at a meeting with the municipality on how to change [Österort], make [Österort] a better place.....t's the last time I will go to such a meeting....Even if there are good intentions...there is a constant focus on people being different, immigrants....What difference does it make? Why does [Österort] have to be different? [Österort] is as much a part of [East City] as [two affluent areas]! Just let it be a part of [East City]. There is too much focus on this stuff....Even if there are good intentions, there is always a focus on...people being immigrants.

Even through the support and care from the municipality are seen to be benevolent, the discourse of aid and support are underpinned by stigmatisation and exclusion, as noted by Sulejman. The position from where the needs and challenges are articulated comes from outside the area, animating and enforcing the distinction as an area of exclusion perceived to be outside the city. Not least, these articulations are underpinned by a repeated emphasis on the migrant background of the residents. However, in a contrasting narrative, resistance towards this discourse can arise. In such contrasting discourses, in the dialectics where these discourses confront each other, a differentiation and a border are animated and introduced.

\subsection{Attributing and Refusing Danger}

In relation to the aforementioned demarcations, two dialectic dimensions of articulating danger vis-à-vis sport practices are constitutive of the place as a domain, concerning both how dangers are located in the places and how the discourse of danger attributed to the places, from positions outside the areas, is refuted in counter-narratives.

First, there is talk about dangers being prevalent, for instance in the form of young people burning cars and throwing stones (Ekholm \& Dahlstedt, 2020). At times, such articulations may be exaggerated and utilised for the purpose of legitimising the activities promoted in the intervention (cf. Hartmann, 2016). However, even such articulations play a role in the discourse animating and forming the places of intervention. Most vividly, Martin (Suburbia FC) in West City recounts the dangers of life in Västerort. He describes how kids "pick up stones, throw them at things," "start fights," how "older guys sit on benches selling bags of stuff," how "you hear people screaming [and] your hear people fighting," how "all your friends are unemployed," and how the area is a "slum...and when you become part of this slum...you risk losing your grip." The situation resonates well with how Darko, an East City Midnight Football coach, describes East City as a place "with a lot of crime, burning cars and a lot of negative things." According to Sead, another coach in East City, "if the Midnight Football wasn't there, the kids would have learned from the older guys...hanging around outside the shopping mall...and believe me, there are no positive things happening there."

This problematisation of impending danger is a discursive underpinning for understanding the sports activities as an intervention to prevent crime and promote social inclusion. Such rationality is also embraced by some of the young people participating in the activities. Saman, a fifteen-year-old boy participating in the West City Midnight Football activities, touches upon the significance of place when describing the relationship between problems and sport as a responding solution and an activity of intervention:

If there is nothing to do at home, there is Midnight Football. Young people go there and play football. When you don't play, you sit down on the benches and just talk about whatever. You're not entirely focused on football....People go there instead of doing bad things, like burning cars and stuff that happened a couple of weeks ago...like selling drugs. There are a lot of criminals in [Västerort]. Especially young people.

Here, the sports intervention appears as both a response and an alternative to the dangers present in the area, in the form of burning cars and selling drugs. Such a discourse forms a strong imagery, recognising that Västerort is a particular place. Thus, as a place, Västerort is constituted as dangerous, and in need of governing intervention.

Second, in the light of the various dangers attributed to the localities, there are counter-narratives, not least in the form of discursive battles with current media discourses. In these counter-narratives, the suburbs are described as not necessarily being more dangerous than other areas of the cities. Accordingly, there can be a variety of animations of the domain that come into conflict with each other. However, these are still articulated with respect to the perceived boundaries and demarcations.

Even after animating the particular dangers above, Martin says that "we never say that we have a problem in [Västerort]-because we don't....Our problem is that other people have a problem with [Västerort]." When reflecting on current discourses in the media, he says:

Do they have to picture it that way? The only thing they want to tell the world is that [Västerort] is a scary 
place. Those who read the papers don't live in the area, and the only information they get is about how bad [Västerort] is....We shouldn't stigmatise these areas.....Stop recounting examples in the media without explaining what lies behind the shootings....There is a structural problem.

Here, the animation of the place is recognised, questioned and countered. Accordingly, the media stigmatises and animates the place in an unfair way, and Martin provides a counter-narrative on the basis of this animation. Furthermore, Martin specifically highlights a repeated focus on danger in his dialogues with both potential partners and supporters of the activities. When Klas recalls a recent visit, he says that other people, "from outside" Västerort, asked him where he would park his car, implying that he cannot park his car within the residential area. But in his counter-narrative, Klas describes Västerort as "a very warm place...filled with people," mentioning that "it is a very open space with the playgrounds and hills and a large green park" next to the sports centre and the football ground where the football activities took place during his visit.

With respect to the situation in East City, Abraham focuses on the images and misinterpretations disseminated by the media. He says that "what is written in the media about fights and guns and stuff...is about real criminals, older people" and not about young people in the area. Therefore, "all these words...are misrepresentations from the media that don't correspond to reality....From the outside, there is so much prejudice about crime and bad things....but that's from people who haven't set foot in this neighbourhood." Notably, this discourse about the situation in the area, as articulated from within, conflicts with the discourse from the outside. Contrasting these conflicting discourses against each other makes the symbolic demarcations of the suburban geography clear. Both discourses are constitutive of the demarcated domains. This formative dialectic, attributing danger while simultaneously refusing such attribution of danger articulated from the outside, facilitates the formation of the domain, constituted by problematisations as well as by discourses about sport as a means of responding to such problematisations.

\section{Discussion and Conclusion}

In this article, we have analysed how the two places of Västerort and Österort are discursively formed as domains of problematisation and governing intervention (cf. Rose, 1999). Accordingly, it is the discourse of social problems and sport as a means of response that facilitates the construction of these places. Places are thus discursively formed in specific ways, but the formation of place also has a political significance and potential which need to be recognised when exploring (cf. Rose, 1999) sports-based interventions, for instance. We argue that the places of intervention are discursively disassociated and demarcated from the rest of society in both material and symbolic dimensions. In this respect, social change is located to the places portrayed as separate from and marked as being outside the city; demarcated from the city and in that sense from society as a whole.

There is a clear discursive pattern throughout the analysis. The places of problematisation and intervention are differentiated in contrast to the discursive outside. In one instance, places are differentiated through the intervention outreach of youth participation and through the recruitment strategies for coaches. In another instance, places are differentiated by marking borders in the suburban geography and ascribing certain meanings, not least in terms of limiting the movements of young people (in particular, the inward movement of young people from the demarcated outside). In a third instance, places are differentiated through the localisation and containment of problems and by pointing out the specific conditions for establishing sport practices. In a fourth instance, places are differentiated by the dialectics between dangers attributed and dangers resisted. Interestingly, and most importantly, differentiations are made not least in a dialectic manner between articulations from the discursive inside (from people residing in the areas) and from the discursive outside (from people and positions outside the areas), against which counter-narratives can be formed, in turn constituting the borders. In the variety of instances, people, attention and language are drawn and directed towards the insides of the places, erecting symbolic borders towards the outsides. Manifestly, this performs the areas of exclusion as the discursive inside. Accordingly, such articulation needs to be viewed as a struggle to form and reform the distinctions between inside and outside the borders, animating the places, or residential areas, as part of the promoted sports-based interventions. Demarcations between inside and outside are not pre-determined but are continually (re)formed in discursive struggles. What is (on) the inside and what is (on) the outside is not given, and even the governing ambitions of development and reform may contribute to the resurrection of symbolic borders. Still, conceptualising the (re)formation of demarcations is important in terms of how people in general, and young people in the areas in particular, make sense of their place in the suburban geography and in society.

Here, the struggle for representation of the place, to articulate the conditions of life in the place, and to animate the domain of intertwined problematisation and technologies of governing, is a matter of opportunities for forming counter-narratives. This aligns with what is referred to in the scientific literature on sportsbased interventions as critical pedagogy (e.g., Nols, Haudenhuyse, Spaaij, \& Theeboom, 2018; Spaaij \& Jeanes, 2013), the development of a counter-conduct (Luguetti, Oliver, Dantas, \& Kirk, 2017) that is potentially facilitated through socio-pedagogical arrangements within sports activities providing pockets of resistance (Sabbe, 2019). For this potential to be realised, 
awareness of the socio-political context of segregation, marginalisation and inequalities needs to be raised and platforms for articulation and resistance need to be provided. In order for practitioners to develop and refine sports-based interventions such as those described in this article, knowledge about the productive power of place needs to be acknowledged. In one instance, this involves the ways in which places are othered, stigmatised and made separate from society as a whole, in turn making them specific targets of governing interventions. Here, opportunities to form critical and emancipatory perspectives and counter-narratives, intrinsic in the socio-pedagogical arrangements of activities, can be fore-fronted. In another instance, knowledge about the significance of place relates to the basic recognition that places differ from each other and that different places have their own conditions that need to be recognised when arranging activities (Ekholm \& Holmlid, 2020). In relation to the concerns raised here, it is necessary to explore the significance and meaning of the football activities and Midnight Football arrangement for the young participants themselves, as well as the potential to provide arenas for resistance. This involves scrutinising the meaning of the sports activities as a place located and enacted within the place of the urban periphery and marginalised areas of exclusion mapped out in this article. This, however, is a future effort within the research project of which this article is a part. In order to understand the meaning and discourse of the young participants in greater detail, we argue, knowledge about how place is animated and constituted in the discourse of problematisations and as subjects of technologies of governing is fundamental. In forthcoming publications, we aim to provide such knowledge on the basis of interviews with the participants briefly introduced here, and on the ethnographic fieldwork conducted at the siteand in the areas-of the intervention activities.

These results on the mobilisation of sports-based interventions as a means of social change, targeting in particular the young people of the urban peripheries, provide knowledge on how place is made and what place in turn can do and enable (cf. Sibley, 1995). Such knowledge contributes to current research on sports-based interventions, where little interest has so far been paid in the scientific literature to further investigating the meaning of specific places where sports interventions are carried out. We have provided one example of how place can be explored as something more than just a surface or a background for specific interventions (cf. Lefebvre, 1991). By interrogating place as a discursive formation and domain, we have provided an opportunity for scrutinising not only how specific meanings are attributed to place and how place is formed, but also the political and governmental potential of place as intertwined in technologies of intervention (cf. Rose, 1999). The discursive formation of place is an ongoing process. It is continually articulated from a variety of actors with different positions, and with different meanings attributed to and as- sociated with the places of problematisation and governing. In these ongoing processes, researchers are also involved in contributing towards and challenging the discourses that are discerned and presented. On the basis of our framework and approach, we hope to provide critical reflections that challenge and problematise how certain places are demarcated as being separate from society and become targets of specific forms of intervention. This contribution has a particular validity for literature on sports-based interventions, but also for research addressing a range of other interventions far beyond the practices of sport.

\section{Acknowledgments}

The authors want to thank James Frempong, Catarina Lack, Nedžad Mešić, Senad Mutic, Anna Oksa, Julia Schossner and Bengt Tall for their contributions in the research project.

\section{Conflict of Interests}

The authors declare no conflict of interests.

\section{References}

Bacchi, C. (2009). Analysing policy: What's the problem represented to be? Frenchs Forest: Pearson.

Bustad, J. J., \& Andrews, D. L. (2017). Policing the void: Recreation, social inclusion and the Baltimore Police Athletic League. Social Inclusion, 5(2), 241-249.

Coalter, F. (2012). 'There is loads of relationships here': Developing a programme theory for sport-for-change programmes. International Review for the Sociology of Sport, 48(5), 594-612.

Coalter, F., Allison, M., \& Taylor, J. (2000). The role of sport in regenerating deprived areas. Edinburgh: University of Edinburgh Press.

Collins, M., \& Haudenhuyse, R. P. (2015). Social exclusion and austerity policies in England: The role of sports in a new area of social polarization and inequality? Social Inclusion, 3(3), 5-18.

Dikec, M. (2017). Urban rage: The revolt of the excluded. New Haven, CT: Yale University Press.

Ekholm, D. (2018). Governing by means of sport for social change and social inclusion: Demarcating the domains of problematization and intervention. Sport in Society, 21(11), 1777-1794.

Ekholm, D. (2019). Mellan självständighet och kontroll: Civilsamhället som samhällsbyggare genom idrott som socialpolitiskt verktyg [Between autonomy and control: The role of civil society in building community through sport as a means of social policy]. In J. Syssner (Ed.), Ett nytt kontrakt för samhällsbyggande? [A new contract for building society?] (pp. 125-150). Stockholm: Linnefors.

Ekholm, D., \& Dahlstedt, M. (2017). Football for Inclusion: Examining the pedagogic rationalities and the tech- 
nologies of solidarity of a sports-based intervention in Sweden. Social Inclusion, 5(2), 232-240.

Ekholm, D., \& Dahlstedt, M. (2018). Rationalities of good-will: On the promotion of philanthropy through sports-based interventions in Sweden. Managing Sport and Leisure, 23(4/6), 336-349.

Ekholm, D., \& Dahlstedt, M. (2019). Pedagogies of (de)liberation: Salvation and social inclusion by means of Midnight Football. Sport, Education and Society. https://doi.org/10.1080/ 13573322.2019.1694504

Ekholm, D., \& Dahlstedt, M. (2020). A model of discipline: The rule(s) of midnight-football and the production of order in subjects and society. Journal of Sport and Social Issues. http://doi.org/10.1177/ 0193723520919818

Ekholm, D., \& Holmlid, S. (2020). Formalizing sportsbased interventions in cross-sectoral cooperation: Governing and infrastructuring practice, program and preconditions. Journal of Sport for Development, 14, 1-20.

Foucault, M. (1972). The archaeology of knowledge. London: Tavistock.

Foucault, M. (1980). Power/knowledge. Harlow: Harvester Press.

Foucault, M. (1982). The subject and power. Critical Inquiry, 8(4), 777-795.

Franzén, M., Hertting, N., \& Thörn, C. (2016). Stad till salu. Entreprenörurbanismen och det offentliga rummets värde [City for sale. Entrepreneurial urbanism and the value of public space]. Gothenburg: Daidalos.

Hartmann, D. (2016). Midnight basketball. Race, sports, and neoliberal social policy. Chicago, IL: The University of Chicago Press.

Kelly, L. (2013). Sports-based interventions and the local governance of youth crime and antisocial behavior. Journal of Sport and Social Issues, 37(3), 261-283.

Lefebvre, H. (1991). The production of space. Oxford: Basil Blackwell.

Luguetti, C., Oliver, K. L., Dantas, L. E. P. B. T., \& Kirk, D. (2017). An activist approach to sport meets youth from socially vulnerable backgrounds. Research Quarterly for Exercise and Sport, 88(1), 60-71.

McSweeney, M., \& van Luijk, N. (2019). Leaving the comfort zone: Utilizing institutional ethnography in sport for development and peace research. Qualitative Research in Sport, Exercise and Health, 11(4), 559-572.

Morgan, H. (2018). Enhancing social mobility within marginalized youth: The accumulation of positive psychological capital through engagement with community sports clubs. Sport in Society, 21(11), 1669-1685.

Nols, Z., Haudenhuyse, R., Spaaij, R., \& Theeboom, M. (2018). Social change through an urban sport for development initiative? Investigating critical pedagogy through the voices of young people. Sport, Education and Society, 24(7), 727-741.

Parker, A., Morgan, H., Farooq, S., Moreland, B., \& Pitchford, A. (2019). Sporting intervention and social change: Football, marginalized youth and citizenship development. Sport, Education and Society, 24(3), 298-310.

Rose, N. (1999). Powers of freedom. Reframing political thought. Cambridge: Cambridge University Press.

Sabbe, S. (2019). Community sport and social cohesion: A social work perspective (Unpublished Doctoral dissertation). Ghent: Ghent University.

Sernhede, O., Thörn, C., \& Thörn, H. (2016). The Stockholm uprising in context. In M. Mayer, C. Thörn, \& H. Thörn (Eds.), Urban uprisings (pp. 149-173). Basingstoke: Palgrave Macmillan.

Sibley, D. (1995). Geographies of exclusion. Society and difference in the West. London: Routledge.

Skinner, J., Zakus, D. H., \& Cowell, J. (2008). Development through sport: Building social capital in disadvantaged communities. Sport Management Review, 11, 253-275.

Spaaij, R., \& Jeanes, R. (2013). Education for social change? A Freirean critique of sport for development and peace. Physical Education and Sport Pedagogy, 18(4), 442-457.

Zukin, S. (1995). The culture of cities. Oxford: Blackwell.

\section{About the Authors}

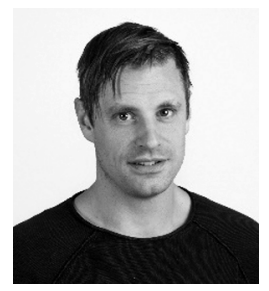

David Ekholm is a Researcher and Lecturer at Linköping University, Sweden. Ekholm's main research interests are in the sociology of social work and social policy. Here, he has a particular focus on youth interventions aiming for social inclusion and utilized by means of sport and leisure activities. Ekholm's research is characterized by critical and constructionist perspectives on contemporary social policy transformations.

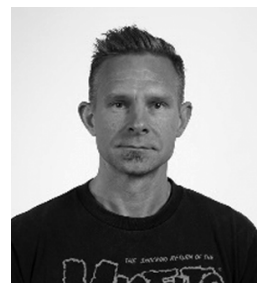

Magnus Dahlstedt is a Professor in social work at Linköping University, Sweden. His research concern citizenship and democracy in times of migration and market-orientation, welfare and social policy changes. Dahlstedt's main research interests are the politics of inclusion/exclusion. In particular, his research is oriented towards the formation of citizenship in the context of the multi-ethnic city, social polarization and social inequality. 